\title{
VIROLOGICAL COURSE OF HERPES ZOSTER IN OTHERWISE NORMAL HOSTS
}

\author{
R. Cevenini, M. Donati, F. Rumpianesi, A. Moroni, A. Tosti*, A. Patrizi*, \\ C. VAROTTI* AND M. NEGOSANTI*
}

Institutes of Microbiology and ${ }^{*}$ Dermatology, University of Bologna, S. Orsola Hospital, 9 Via Massarenti, 40138 Bologna, Italy

\begin{abstract}
SUmmary. The virological course of herpes zoster infection in 42 otherwise normal hosts was studied by virus isolation and antibody titration. Varicella-zoster virus (VZV) was isolated from vesicle fluid from all three patients examined on the first day of the vesicular eruption and from five out of six examined on the second day. The isolation rate fell to one out of six patients on the seventh day of illness and VZV was not isolated from patients at a later stage of the illness. IgG antibodies were detected by IFAMA and ELISA, in sera from all the patients by the end of the first week of illness; IgG antibody titres were highest during the second and the third weeks. IgM antibodies to VZV were detected in sera from six of the $\mathbf{4 2}$ patients with herpes zoster after fractionation by ion-exchange chromatography.
\end{abstract}

\section{INTRODUCTION}

Varicella-zoster virus (VZV) is a member of the herpes group, and shares several biological characteristics with Herpes simplex virus. These include the ability to establish latency during the primary infection, and subsequently to be reactivated, despite the presence of circulating antibodies (Bastian et al., 1974; Joncas, 1979). Initial infection by VZV causes varicella. After clinical recovery there is lifelong immunity to exogenous reinfection but reactivation of the original infection may occur in the form of herpes zoster.

VZV may adversely affect immunosuppressed patients such as those with cancer (Schimpff et al., 1972) or the recipients of organ transplants in whom the natural resolution of either primary or reactivated infections may not occur. Consequently, most virological studies of the natural history of VZV infection have been made on very selected populations of immunosuppressed patients, and little information is available about the virological course of VZV infections in normal subjects (Gold, 1966). Some studies of the duration of virus excretion and the quantity of lesions have been reported in immunocompromised patients (Johnson et al., 1975; Whitley et al., 1976) but the results cannot be extrapolated to normal hosts. Moreover, the 
virological course of VZV infection in normal hosts needs careful definition, in order to design proper clinical trials of the therapeutic efficacy of antiviral drugs.

The purpose of this study was to define the virological course of herpes zoster in $\mathbf{4 2}$ normal hosts by isolation of the virus and by antibody titration during the acute phase and convalescence.

\section{MATERIALS AND METHODS}

Patients and controls. Forty-two otherwise healthy patients, aged 25-75 years, in hospital with localised herpes zoster, were studied. Serum samples were taken 7, 14, 21, 28, 60 and 180 days after the onset of the illness. Specimens of vesicle fluid for virus isolation were obtained during the 8 days after the appearance of the vesicles; samples from 24 patients were collected within the first 4 days of illness, from 12 patients between the fifth and seventh days and from six patients on the eighth day.

Single samples of serum were collected from 20 healthy subjects, aged 25-35 years, who had had varicella 10-20 years previously, and 10 healthy subjects, aged 12-21 years, with no past history of varicella as controls. The presence of antibody to VZV was determined by immunofluorescence for antibody to membrane antigen (IFAMA) and enzyme-linked immunosorbent assay (ELISA).

Cell culture. Human embryonic fibroblasts (HEF) were grown in Eagle's minimal essential medium (MEM) supplemented with fetal calf serum (FCS) $10 \%$ and streptomycin $128 \mathrm{mg} / \mathrm{L}$.

$V Z V$ isolation and identification. Fluid was aspirated from vesicles with a syringe and diluted in $0.5 \mathrm{ml}$ of Eagle's MEM with inactivated FCS $20 \%$, and immediately inoculated into HEF cultures. VZV was identified by an indirect immunofluorescence technique with anti-VZV rabbit hyperimmune serum.

Immunofluorescence for antibody to membrane antigen. The IFAMA technique was performed as described by Leventon-Kriss et al. (1978). Cells infected with VZV and control cells were suspended in PBS, dropped on to slides and allowed to dry. A twofold dilution of serum in PBS was added, incubated at $37^{\circ} \mathrm{C}$ for $45 \mathrm{~min}(\mathrm{IgG})$ or $3 \mathrm{~h}(\mathrm{IgM})$ and the slide washed in PBS. The cells were then treated for $30 \mathrm{~min}$ with fluorescein-conjugated rabbit anti-human IgG or IgM (Wellcome, Beckenham, England), and washed in PBS. Slides were mounted with glycerol $10 \%$ in PBS and viewed in a UV microscope (Zeiss).

Enzyme-linked immunosorbent assay (ELISA). Crude VZV antigen was produced by infecting HEF with the Nurit 521 strain of VZV, kindly supplied by Professor I. Sarov, Beer Sheva, Israel. After $48 \mathrm{~h},>80 \%$ of the cells showed a cytopathic effect. The monolayers were washed twice with PBS and frozen and thawed three times. After ultrasonic treatment, debris was removed by centrifugation at $1500 \mathrm{~g}$ for $20 \mathrm{~min}$. The supernate was stored at $-70^{\circ} \mathrm{C}$ and used as antigen. The control antigen was prepared from uninfected HEF treated in the same way. The protein concentration of antigen and control were determined by the method of Lowry et al. (1951).

The ELISA test was performed as described previously (Cevenini, Donati and Rumpianesi, 1981). The VZV and control antigens were diluted to a final protein concentration of $200 \mu \mathrm{g} / \mathrm{ml}$, in carbonate-bicarbonate coating buffer $\left(0.03 \mathrm{M} \mathrm{Na} \mathrm{CO}_{3}\right.$ and $\mathrm{NaN}_{3} 0.02 \%, p \mathrm{H} \mathrm{9.6)} ; 0.2 \mathrm{ml}$ of antigen was added to each well of micro-ELISA plates (Dynatech MI29A). After incubation at room temperature for $12 \mathrm{~h}$, the plates were washed three times; $0.2 \mathrm{ml}$ of serial doubling dilutions of sera (from 1 in 80 to 1 in 40 960) in a dilution buffer (PBS-Tween-20,pH 7.5) was added and incubated at room temperature for $2 \mathrm{~h}$. The plates were then washed three times and $0.2 \mathrm{ml}$ of anti-human IgG or IgM conjugated with alkaline phosphatase (Orion Diagnostic, Helsinki, Finland), diluted 1 in 100, was added to each well. The mixture was incubated for $3 \mathrm{~h}$ at room temperature and then washed as described above. Thereafter, $0.2 \mathrm{ml}$ of Sigma 104 substrate (p-nitrophenyl phosphate, disodium salt) $1 \mathrm{mg} / \mathrm{ml}$ in $10 \%$ diethanolamine buffer, was added to each well and incubated for $30 \mathrm{~min}$ at room temperature. The reaction was stopped by adding $0.05 \mathrm{ml}$ of $2 \mathrm{M} \mathrm{NaOH}$. Absorbance was read at $405 \mathrm{~nm}$ in a Dynatech Microelisa auto reader MR,580.

Rheumatoid factor. The sera were tested for the presence of rheumatoid factor (RF) by the Rheuma Wellco latex agglutination test (Wellcome, Beckenham, England). 
IgM purification. IgM was separated from IgG by ion-exchange chromatography with QAE-Sephadex A-50 (Pharmacia Fine Chemicals, Uppsala, Sweden; Johnson and Libby, 1980). A 250- $\mu$ l sample of serum diluted in $5 \mathrm{ml}$ of ethylenediamine:glacial acetic acid: $\mathrm{H}_{2} \mathrm{O}$ $(2 \cdot 88: 4 \cdot 38: 1000$-w:w:v) was passed through a column packed with Sephadex A-50 at a flow rate of $0.5 \mathrm{ml} / \mathrm{min}$. The IgM fraction was eluted with $1.5 \mathrm{ml}$ of eluting solution-glacial acetic acid:sodium acetate. $3 \mathrm{H}_{2} \mathrm{O}$ :sodium chloride: $\mathrm{H}_{2} \mathrm{O}$ (15·65:10.6:20:1000-w:w:w:v). The eluent contained a 1 in 8 dilution of the original serum IgM, but no IgG (Johnson and Libby, 1980).

\section{RESULTS}

The isolation of VZV from vesicle fluid collected on the 8 days after the onset of illness is shown in the table. VZV was not isolated from specimens collected on the eighth day.

The antibody response during herpes zoster was measured by IFAMA and ELISA. IgG antibodies to VZV were detected by IFAMA in sera collected at the beginning of

TABLE

$V Z V$ isolation from vesicle fuid collected during the first 8 days of the illness

\begin{tabular}{ccc}
\hline $\begin{array}{c}\text { Day of } \\
\text { sampling }\end{array}$ & $\begin{array}{c}\text { Number of patients } \\
\text { examined }\end{array}$ & $\begin{array}{c}\text { Number of patients from } \\
\text { whom VZV was isolated }\end{array}$ \\
\hline 1 & 3 & 3 \\
2 & 6 & 5 \\
3 & 8 & 6 \\
4 & 7 & 5 \\
5 & 6 & 0 \\
6 & 0 & 1 \\
7 & 6 & 0 \\
8 & 6 & 23 \\
Total & 42 & \\
\hline
\end{tabular}

the illness. The titres of IgG antibodies increased fourfold during the second and third weeks and decreased thereafter. The changes in anti-VZV IgG detected by ELISA were similar (fig. 1). The mean antibody titres detected by ELISA were 50-100 times higher than those by IFAMA. There was a positive correlation $(r=0 \cdot 70)$ between the titres of anti-VZV antibody measured by IFAMA and ELISA in sera from patients with zoster (fig. 2). Anti-VZV antibodies were not detected in sera from 10 subjects with no clinical history of varicella. Antibodies were detected by IFAMA in sera from 18 out of 20 healthy adults with a previous history of varicella; titres were in the range 2-16 (mean 4).

Anti-VZV IgM antibodies were detected by IFAMA in 20 out of the 42 patients with herpes zoster examined at the end of the second week of illness; the mean titre was 20.7. Anti-VZV IgM antibodies were detected by ELISA in sera from 17 patients; the mean titre was 235 . RF was detected by the latex agglutination test in sera from 12 of the 20 patients with anti-VZV IgM antibodies. The IFAMA and ELISA tests for IgM were performed on the chromatographically purified IgM fractions of these 20 sera to test the specificity of the IFAMA and ELISA tests for anti-VZV IgM antibody. Specific anti-VZV IgM was detected in four of the eight sera negative for RF, and in two of the 12 sera positive for RF. 


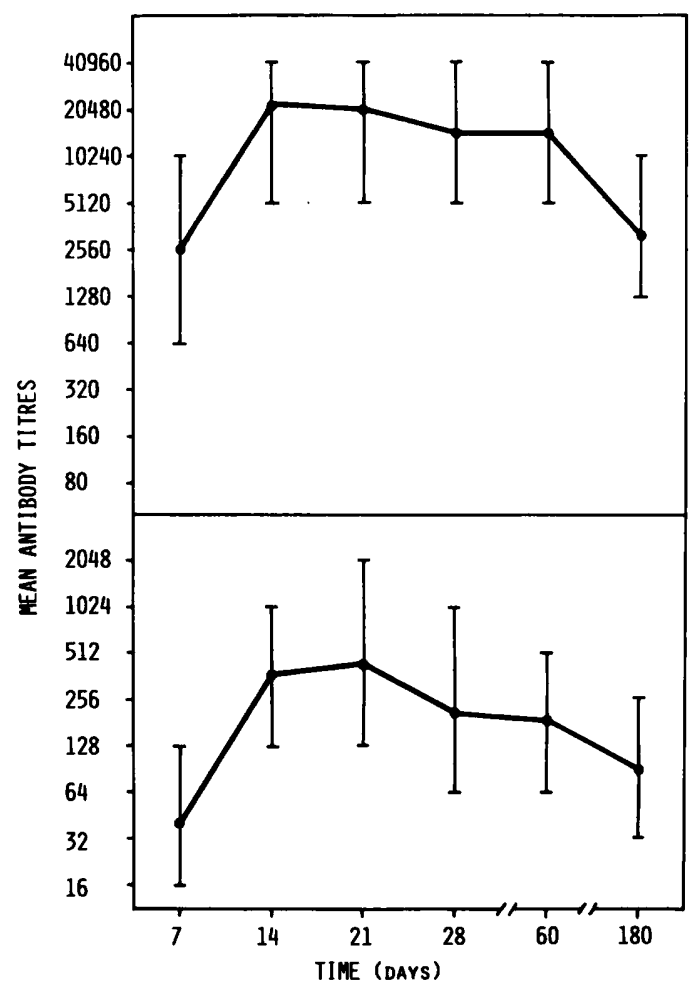

Fig. 1.-Anti-VZV IgG titres in patients with herpes zoster at various times after the appearance of the vesicles, determined by ELISA (upper graph) and IFAMA (lower graph). Each point represents the geometric mean value and the vertical bars represent the range of variation.

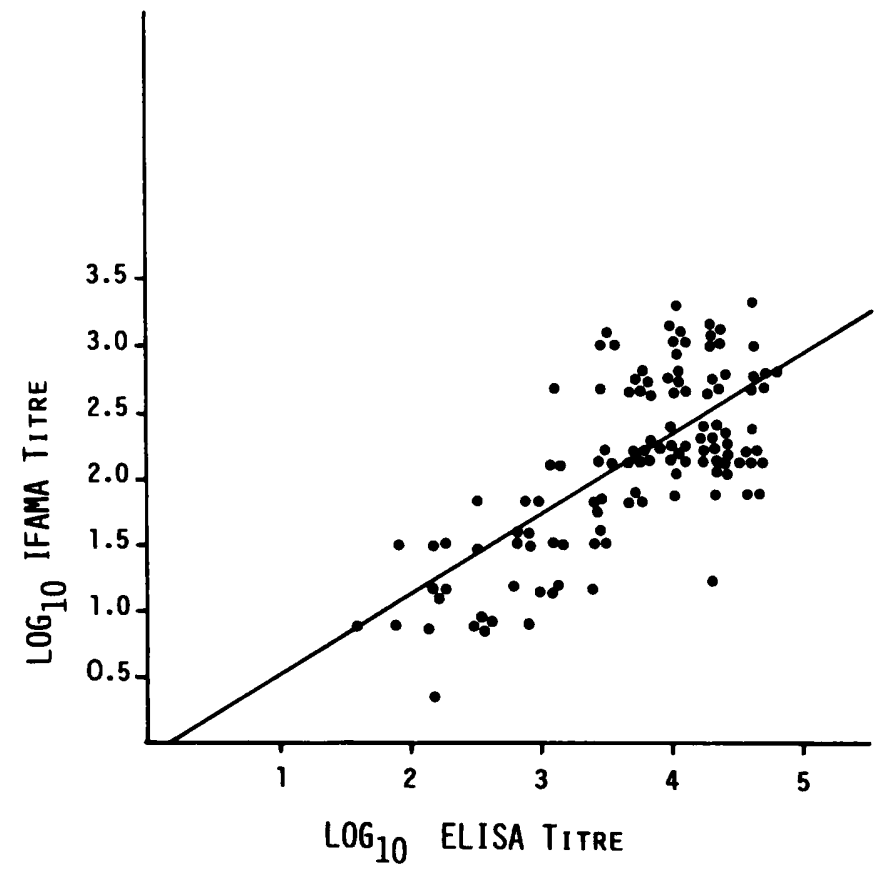

Fig. 2.-Correlation between antibody titres obtained by IFAMA and ELISA in patients with herpes zoster $(n=122 ; y=0.60 x-0.10 ; r=0.70)$. 


\section{DisCUSSION}

VZV was isolated from all three patients examined on the day that the first vesicles appeared and from five of the six patients examined on the second day. The isolation rate fell to one out of six patients examined on the seventh day of illness. Shedding of VZV had ceased in all patients by the eighth day of illness, in contrast with the findings in immunocompromised hosts. Whitley et al. (1976) reported that c. $20 \%$ of immunocompromised patients with active herpes zoster shed virus up to the tenth day of illness. VZV may have cleared from the lesions more slowly in these patients because of the underlying illness, than in the otherwise normal subjects in our study.

One week after the onset of herpes zoster, IgG antibodies were detected by IFAMA and ELISA in sera from all the patients, although some differences in antibody titre between the two tests were observed. However, no correlation was found between antibody titre and the clinical course of the disease. In all patients, the titre reached a peak during the second and the third weeks of the illness. Most of the subjects $(90 \%)$ with a past history of varicella had low titres of antibodies against VZV, as reported by other authors (Williams, Gershon and Brunell, 1974; Haikin, Leventon-Kriss and Sarov, 1979).

IgG responses are characteristic of secondary antigenic stimulation but IgM responses have been reported in herpes zoster (Ross and McDaid, 1972; Arvin and Koropchak, 1980; Hacham, Leventon-Kriss and Sarov, 1980; Tedder, Mortimer and Lord, 1981). However, other authors could not detect specific anti-VZV IgM (Schmidt and Lennette, 1975; Gerna et al., 1979). In the present study, we detected specific anti-VZV IgM in the sera of six of 42 patients with herpes zoster. ELISA and IFAMA were sensitive and reliable techniques for the detection of specific anti-VZV IgG antibodies, and there was a positive correlation $(r=0.70)$ between the two techniques.

The direct determination of anti-VZV IgM antibodies in the sera of patients with herpes zoster by ELISA and IFAMA, without fractionation, was practicable, but gave some false positive results. Without fractionation, anti-VZV IgM was detected in 20 of the 42 patients with herpes zoster, but after fractionation, specific anti-VZV IgM was detected in only two of the 12 RF-positive sera, and four of the eight RF-negative sera. Four sera out of the eight that did not react in the "Rheuma" test nevertheless appeared to contain RF, because after purification they no longer contained specific anti-VZV IgM. However, some sera, RF-negative by latex agglutination give false positive IgM fluorescence that was eliminated by absorption of the RF by heat-aggregated human gamma globulin (Shirodaria, Fraser and Stanford, 1973; Nikoskelainen and Hanninen, 1975). Because of the possibility of false positive IgM tests, it seems advisable to consider all sera from patients with zoster as RF-positive and to treat them to remove RF before testing for anti-VZV IgM. This report concentrates on the natural history of herpes zoster in normal hosts. A careful definition of the virological course of herpes zoster in normal hosts is important for a proper evaluation of the therapeutic activity of antiviral agents. The pain of herpes zoster and postherpetic neuralgia are significant problems and effective therapy for herpes zoster in the normal host is an urgent goal.

We thank Mr L. Franchi for excellent technical work. 


\section{REFERENCES}

ARVIN, A. M. AND KOROPCHAK, C. M. 1980. Immunoglobulin M and immunoglobulin G to Varicella-zoster virus measured by solid-phase radioimmunoassay: antibody responses to varicella and herpes zoster infections. Journal of Clinical Microbiology, 12, 367-374.

Bastian, F. O., Rabson, A. S., Yee, C. L. and Tralka, T. S. 1974. Herpes virus varicellae isolated from human dorsal root ganglia. Archives of Pathology, 97, 331-333.

Cevenini, R., Donati, M. AND Rumpianesi, F. 1981. Elementary bodies as single-antigen in a micro-ELISA test for Chlamydia trachomatis antibodies. Microbiologica, 4, 347-351.

Gerna, G., Cereda, P. M., Cattaneo, E., Achilli, G. and Gerna, M. T. 1979. Antibody to early antigens of Varicella-zoster virus during varicella and zoster. Journal of Infectious Diseases, 140, 33-41.

GoLD, E. 1966. Serologic and virus-isolation studies of patients with varicella or herpes-zoster infection. New England Journal of Medicine, 274, 181-185.

Hacham, M., LeVENTON-Kriss, S. AND SaRov, I. 1980. Enzyme-linked immunosorbent assay for detection of virus-specific IgM antibodies to Varicella-zoster virus. Intervirology, 13, 214-222.

Haikin, H., Leventon-Kriss, S. and Sarov, I. 1979. Antibody to Varicella-zoster virusinduced membrane antigen: immunoperoxidase assay with air-dried target cells. Journal of Infectious Diseases, 140, 601-604.

Johnson, M. T., Luby, J. P., Buchanan, R. A. And Mikulec, D. 1975. Treatment of Varicella-zoster virus infections with adenine arabinoside. Journal of Infectious Diseases, 131, 225-229.

JOHNSON, R. B. AND LIBBY, R. 1980. Separation of immunoglobulin M (IgM) essentially free of IgG from serum for use in systems requiring assay of IgM-type antibodies without interference from rheumatoid factor. Journal of Clinical Microbiology, 12, 451-454.

JoNCAS, J. H. 1979. Persistence, reactivation and cell transformation by human herpes viruses: Herpes simplex, 1,2 (HSV-1, HSV-2), Cytomegalovirus (CMV), Varicella-zoster (VZV), Epstein-Barr virus (EBV). Canadian Journal of Microbiology, 25, 254-260.

LeVenton-Kriss, S., Yoffe, R., RANNON, L. AND MOdAN, M. 1978. Seroepidemiologic aspects of Varicella-zoster virus infections in an Israeli Jewish population. Israel Journal of Medical Sciences, 14, 766-770.

Lowry, O. H., Rosebrough, N. J., Farr, A. L. ANd Randall, R. J. 1951. Protein measurement with Folin phenol reagent. Journal of Biological Chemistry, 193, 265-275.

Nikoskelainen, J. and Hanninen, P. 1975. Antibody response to Epstein-Barr virus in infectious mononucleosis. Infection and Immunity, 11, 42-51.

Ross, C. A. C. AND MCDAID, R. 1972. Specific IgM antibody in serum of patients with herpes zoster infections. British Medical Journal, 4, 522-523.

Schimpfr, S., Serpick, A., Stoler, B., Rumack, H., Mellin, J. M. ANd Block, J. 1972. Varicella-zoster infection in patients with cancer. Annals of Internal Medicine, 76, 241-254.

SCHMIDT, N. J. AND LENNETTE, E. H. 1975. Neutralizing antibody responses to Varicella-zoster virus. Infection and Immunity, 12, 606-613.

Shirodaria, P. V., Fraser, K. B. AND StanFord, F. 1973. Secondary fluorescent staining of virus antigens by rheumatoid factor and fluorescein-conjugated anti IgM. Annals of the Rheumatic Diseases, 32, 53-57.

TeDder, R.S., MorTimer, P. P. AND LoRD, R. B. 1981. Detection of antibody to Varicella-zoster virus by competitive and IgM-antibody capture immunoassay. Journal of Medical Virology, 8, 89-101.

Whitley, R. J., Ch'ien, L. T., Dolin, R., Galasso, G. J. and Alford, C. A. and The Collaborative Study Group. 1976. Adenine arabinoside therapy of herpes zoster in immunosuppressed. NIAID collaborative antiviral study. New England Journal of Medicine, 294, 1193-1199.

Williams, V., Gershon, A. AND BRunell, P. A. 1974. Serologic response to Varicella-zoster membrane antigens measured by indirect immunofluorescence. Journal of Infectious Diseases, 130, 669-672. 